Research Paper

\title{
The Legal Aspects in the Implementation of CSR Private Corporate Towards Improvement of Community Welfare
}

\section{Sandra Dewi ${ }^{1}$}

${ }^{1}$ Faculty of Law, Universitas Lancang Kuning. Indonesia.

Article History

Received:

15.01 .2020

Revised:

14.02.2020

Accepted:

24.03.2020

*Corresponding Author:

Sandra Dewi

Email:

sandradewi@unilak.ac.id

This is an open access article, licensed under: $\mathrm{CC}-\mathrm{BY}-\mathrm{SA}$

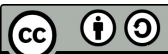

Abstract: There are 33 private companies with large investment value in Pelalawan Regency, Riau Province. Article 74 of Law Number 40 of 2007 affirms that companies that carry out their business activities in the field of natural resources and / or fields related to natural resources must implement Corporate Social Responsibility. However, the implementation of Corporate Social Responsibility of these private companies is very minimal felt by the community because Pelalawan Regency is the second most populous region in Riau Province. This research aims to explain the legal issues in the implementation of Corporate Social Responsibility of private companies to improve community welfare in Pelalawan Regency, Riau Province. The method used in this research is socio-legal research. The results of this research explain that there are several legal issues that cause the implementation of Corporate Social Responsibility of private companies in Pelalawan Regency not running optimally, namely the absence of local regulations that specifically regulate Corporate Social Responsibility in Pelalawan Regency, the lack of supervision from the government regions, the lack of legal knowledge of the Pelalawan Regency community regarding Corporate Social Responsibility, and the absence of strict criminal sanctions for companies that do not implement Corporate Social Responsibility in Regional Regulation No. 6 of 2012 concerning Corporate Social Responsibility in Riau Province.

Keyword: Corporate Social Responsibility, Law, Welfare. 